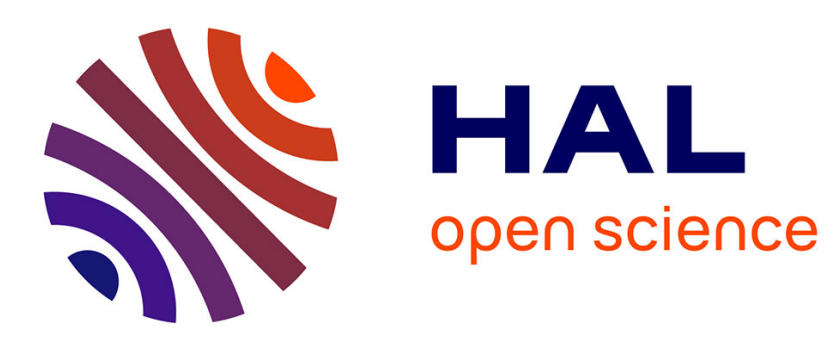

\title{
Nonchemical weeding of medicinal and aromatic plants
}

\author{
Alessandra Carrubba, Marcello Militello
}

\section{To cite this version:}

Alessandra Carrubba, Marcello Militello. Nonchemical weeding of medicinal and aromatic plants. Agronomy for Sustainable Development, 2013, 33 (3), pp.551-561. 10.1007/s13593-012-0122-9 . hal01201365

\section{HAL Id: hal-01201365 \\ https://hal.science/hal-01201365}

Submitted on 17 Sep 2015

HAL is a multi-disciplinary open access archive for the deposit and dissemination of scientific research documents, whether they are published or not. The documents may come from teaching and research institutions in France or abroad, or from public or private research centers.
L'archive ouverte pluridisciplinaire HAL, est destinée au dépôt et à la diffusion de documents scientifiques de niveau recherche, publiés ou non, émanant des établissements d'enseignement et de recherche français ou étrangers, des laboratoires publics ou privés. 


\title{
Nonchemical weeding of medicinal and aromatic plants
}

\author{
Alessandra Carrubba $\cdot$ Marcello Militello
}

Accepted: 13 November 2012 /Published online: 12 December 2012

(C) INRA and Springer-Verlag France 2012

\begin{abstract}
Medicinal and aromatic plants are major crops of domestic and industrial interest. Medicinal and aromatic plants are increasingly organically grown to enhance profitability. However, the presence of weeds may lead to a decrease in both yield and quality. Therefore, nonchemical methods of weed control are needed. In this study, mechanical weeding, flaming, stale seedbed, and biodegradable mulch were tested from 2003/2004 to 2006/2007 on coriander, fennel, and psyllium. Biomass and seed yield were measured. The biomass of weeds remaining at harvest was also measured. Results show a high sensitivity of coriander, fennel, and psyllium crops to the presence of weeds. Stale seedbed excessively delayed sowing time, thus inducing negative effects on crop seed yields. As a consequence, seed yield was $40-90 \%$ lower than in the untreated plots. On the other hand, mechanical weeding, flaming, and biodegradable mulch reduced weeds by $50-95 \%$.
\end{abstract}

Keywords Medicinal and aromatic plants - Coriander . Coriandrum sativum L. · Fennel · Foeniculum vulgare Mill. · Psyllium · Plantago psyllium L. · Sustainable agriculture · Cropping techniques

\section{Introduction}

Medicinal and aromatic plants embrace a large number of plant species, dealing with different botanical, agronomic, and industrial features, endowed with specific properties that, in general terms, make them useful in therapy or prevention of

A. Carrubba $(\square) \cdot$ M. Militello

Department of Agro-Environmental Systems (D/SAGA),

University of Palermo, Viale delle Scienze,

90128 Palermo, Italy

e-mail: alessandra.carrubba@unipa.it diseases or for seasoning foods. Coriander (Coriandrum sativum L.) and fennel (Foeniculum vulgare Mill.), belonging to the family Apiaceae (formerly Umbelliferae), are two annual (sometime biennial) herbs mainly grown to collect their aromatic seeds. Both are native and largely widespread inside the Mediterranean, where they have been in use for centuries for cooking or for medicinal purpose (Carrubba et al. 2008; Diederichsen 1996; WHO 2007). Psyllium (Plantago psyllium L.) is a Mediterranean annual medicinal plant belonging to the family Plantaginaceae. Psyllium seeds are rich in water-soluble fibers (mucilages) that, after absorbing water increase in volume up to tenfold or more. This is the reason why psyllium seeds are abundantly used by pharmaceutical industry as a dietary and phytotherapic supplement, useful in slimming diets and for the treatment of some intestinal disorder (Marlett and Fischer 2003; WHO 1999; Fig. 1).

The common point to all medicinal and aromatic plants, including the three above, is the presence, inside the whole plant or in only a part of it, of one or more secondary metabolites that confer to each species its specific and valuable properties. Hence, such plants have been used by mankind for thousands of years and, in many places on Earth, still represent the basic traditional sources for many food and medicinal items (Carrubba and Scalenghe 2012; Padulosi et al. 2002; WHO 2003).

Medicinal and aromatic plants often represent a crucial component in wild flora, and in their traditional utilization form, they were collected from the wild. However, for many reasons, today, this supply method is no longer suitable to the needs of industry; hence, interest towards the cultivation of medicinal and aromatic plants on a medium-large scale is increasing (Carrubba and Catalano 2009; Schippmann et al. 2002; WHO 2003).

These crops find an important role in organic farming systems, since organic cultivation allows to enhance their 


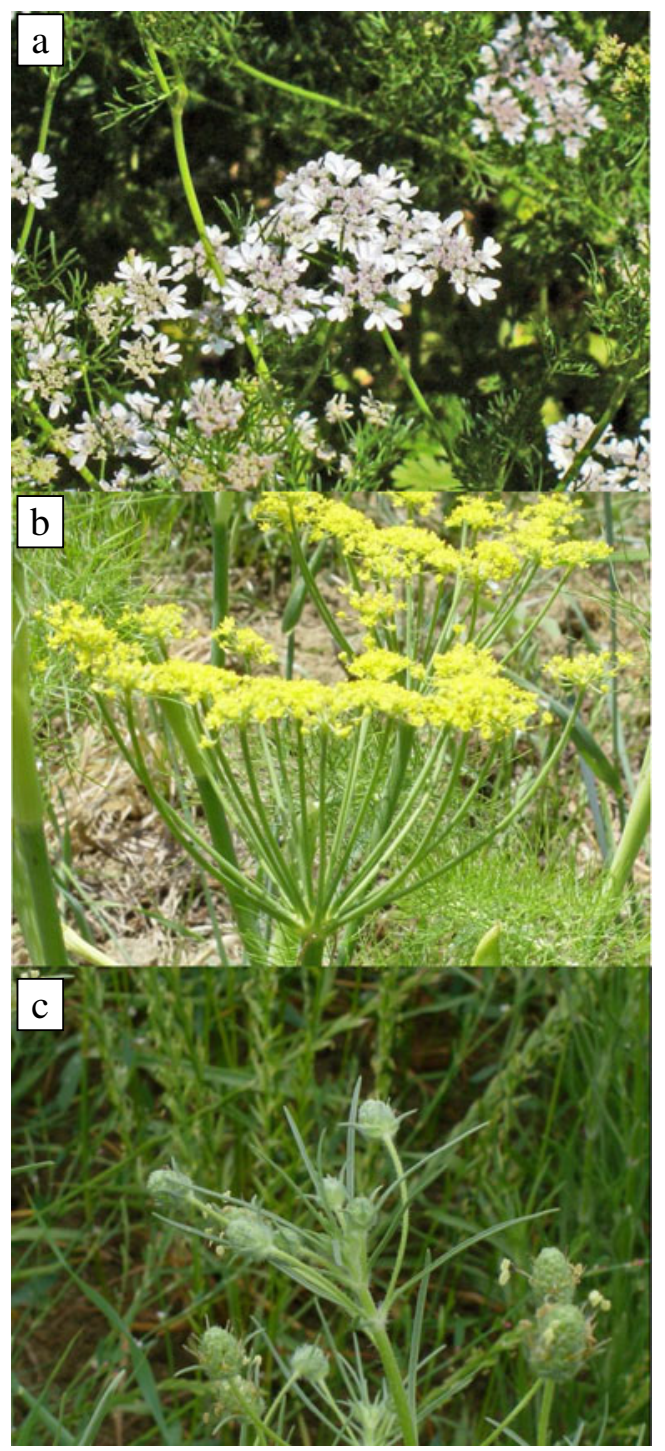

Fig. 1 Coriander (Coriandrum sativum L.. Apiaceae) (a), fennel (Foeniculum vulgare Mill.) (b), psyllium (Plantago psyllium L.) (c), three Mediterranean herbs cultivated for their valuable seeds

end quality, for which buyers are often willing to pay a considerably higher price. This is the main reason why a noticeable area invested with medicinal and aromatic plants is cultivated with the organic production system, which does not allow use of chemicals (European Herb Growers Association 2010).

Actually, many medicinal and aromatic plants are spontaneous plants driven to cultivation after they are discovered to be of some economic value and have not been submitted to a long-lasting genetic improvement process as most of the cultivated crops. Many problems arise when a plant moves from the condition of wild to that of cultivated species; they often show noncompetitive behavior with no desirable features for crops as found in wild plants, such as a prolonged flowering period, a tendency to scatter seeds, and a low harvest index (Schippmann et al. 2002; Carrubba and Catalano 2009).

In such conditions, weed management is a major constraint. As with all commonly grown crops, also in medicinal and aromatic plants, weeds function as crop competitors, create problems for mechanized harvest, and may alter the end quality when mixed with the harvested product. The well-known interference of weeds takes additional relevance for medicinal and aromatic plants for several reasons. Firstly, the synthesis of secondary metabolites in plants is linked to many genetic and environmental factors (Sangwan et al. 2001). Buyers often grade such plants according to their specific quality features, which are primarily determined by their content in essential oils or other secondary metabolites, which on their turn can be reduced in presence of weeds (Carrubba and Catalano 2009). Although sparse specific experiments have been conducted, the presence of weeds is therefore believed to exert a significant effect on plant metabolic pathways, in this way acting negatively on the market end value of such crops (Gil et al. 1998).

Furthermore, especially in those crops where seeds are collected, weed competition has to be avoided to guarantee certain yield. Some experiments carried out on suitability of medicinal and aromatic plants to field conditions have confirmed the importance of weed competition; de la Fuente et al. (2003) demonstrated that on coriander, especially under poor soil conditions, weeding had a greater effect than did $\mathrm{N}$ fertilization.

However, there are few literatures dealing with weed control in medicinal and aromatic plants. Additional information is required about, for instance, the mechanisms that underlie competition in such crops, in order to determine the intervention thresholds for each species and product. Few studies on management tools suitable for weed control have been undertaken so far. Chemical weed control has been tested for certain species, including coriander (C. sativum L.), mint (Mentha piperita L. and Mentha arvensis var. piperascens Malinv.), blessed thistle (Silybum marianum Gaertn.), fennel (F. vulgare Mill.), sage (Salvia officinalis L.), savory (Satureja officinalis L.), and thyme (Thymus officinalis L.) (Kothari et al. 1989; Pank 1992; Zheljazkov et al. 1996; Zheljazkov et al. 2006). Following these authors, if phytotoxic effects were avoided, the use of pendimethalin, fluchloralin, and other chemicals did not affect seed or oil yields or oil quality. However, interest in chemical weed control in medicinal and aromatic plants is low because, increasingly, their production involves cultivation using organic methods, which, according to EU regulations (EU Reg. 2092/91 and 2078/92), prohibit the use of chemicals. Despite clear guidelines for the proper management of crops under organic conditions (DeMarco et al. 1999), such management is often not enough to keep weed populations below the tolerance threshold in sensitive crops. Therefore, 
there is great interest in developing effective alternative nonchemical methods (agronomic, biological and physical) for weed control as developed for certain vegetable crops such as carrots (Peruzzi 2005), spinach (Peruzzi 2006), and leek and onion (Melander and Rasmussen 2001). In organic management, many approaches have been suggested, both direct and indirect, involving a wide range of mechanical equipment (van der Weide et al. 2008), biological means, and agronomic strategies (Barberi 2002; Bond and Grundy 2001; Smith et al. 2000). Most, however, have not been adequately tested in cultivation of medicinal and aromatic plants, and their use is not common among farmers, who, without convenient alternatives, tend to solve weed problems by hand weeding, which is an important limiting factor to encourage their organic cultivation.

Mechanical weeding is certainly the most immediately applicable method for weed management when the use of chemicals is undesirable (Chicouene 2007). Sometimes, mechanical weeding needs to be supported by the adoption of special techniques, such as sowing in double instead of single rows, as successfully tried for oregano (Carrubba et al. 2002). In fact, one of the greatest difficulties in mechanical weed control is planning crop arrangement in space, that is, considering from the outset the kind of equipment that will be used for weeding and then setting appropriate interrow distances. Many failures of mechanical weeding are linked to neglect of this aspect of management (Carrubba and Catalano 2009).

Flame control has been suggested as a convenient nonchemical method (Bond and Grundy 2001); it is performed with special equipment that, when passed over and around weeds, quickly boils the water in their cells, causing wilting of the apex and ultimately death. Flaming controls many annual weeds completely, but it is less effective against perennial weeds, which will send up new shoots soon after flaming; therefore, additional treatments are often required (Ascard 1995). Experiments about flaming in medicinal and aromatic plants have concerned sage and lavender, two perennials (Martini 1996), where this technique demonstrated a satisfactory ability in controlling weeds, above all when associated with inter-row hoeing. To our knowledge, our experiment is the only one that has been performed by far on the effect of flaming on annual medicinal and aromatic plants; some data on coriander and fennel have been already published (Carrubba et al. 2009), enlightening the influence on seeds yield of seasonal climatic patterns.

An alternative environmentally friendly technique, suggested for many row crops even under organic cropping conditions (Anzalone, et al. 2010; Cirujeda et al. 2012; Rasmussen et al. 2011), is mulching. A few experiments on mulching have been conducted on medicinal and aromatic plants. In cultivation trials of Artemisia absinthium, a perennial herb, mulching resulted in a $5 \%$ increase in average plant weight (Giorgi et al. 2006). Other perennials such as lavender (Lavandula angustifolia Chaix), thyme (Thymus vulgaris L.), and rosemary (Rosmarinus officinalis L.) have often shown significant increases in mean plant height and diameter with mulching (Fontana et al. 2006). Growers have obtained good results using polyethylene mulch or black porous plastic (Galambosi and Szebeni-Galambosi 1992). However, natural materials such as cereal straw, flax straw, nonwoven wool, or pine needles have also been tried, with success varying according to species, environmental conditions, and the nature of the organic materials used (Carrubba and la Torre 2005; Cirujeda et al. 2012; Duppong et al. 2004; Kasirajan and Ngouajio 2012). Furthermore, the position of the mulch may vary; it may be placed between crop rows after emergence or transplant (before the emergence of weeds), or laid at the time of sowing with the crop seeds (or plants) inserted through holes in the mulch. These management choices will affect weed populations quite differently because, in the first case, more room will be available for weeds in proximity of the crop, hence, the method should be chosen according to the acceptable level of weed infestation. A further complication is that the chosen mulching technique can lead to some variation in plant chemical traits (Duppong et al. 2004).

Finally, a widely advised method for organic field management is the stale or false seedbed technique (Barberi 2002; Bond and Grundy 2001; Rasmussen et al. 2011), which affects potential weed flora by first promoting weed seedling emergence with shallow soil work and then destroying the seedlings with subsequent soil work. Results demonstrate that this technique can increase the chance of crop establishment, especially when season does not run dry (Bond and Grundy 2001).

In this work, we present the results of a trial designed to evaluate the effects of some environmentally friendly techniques for weed management that are thought to be feasible in Mediterranean organic cropping systems on the seeds yield of three selected medicinal and aromatic plants of Mediterranean origin: coriander, fennel, and psyllium.

\section{Materials and methods}

\subsection{Field management and experimental layout}

This trial was carried out from 2003-2004 to 2006-2007 at the experimental farm Sparacia (Cammarata, AG, Sicily; $37^{\circ} 38^{\prime} \mathrm{N}-13^{\circ} 46^{\prime} \mathrm{E} ; 415 \mathrm{~m}$ a.s.1.). Three Mediterranean annual herbs were studied: coriander (C. sativum L.), fennel (F. vulgare Mill.), and psyllium (P. psyllium L.).

Each year before sowing, the soil was ploughed to 30 $35 \mathrm{~cm}$ by means of a tractor-drawn moldboard plow. 
Thereafter, the seedbed was prepared according to the ordinary scheme by means of shallow harrowing just before sowing using a 2-m-wide fixed teeth harrow working at $10 \mathrm{~cm}$ depth.

The used experimental scheme was a randomized complete block design, re-randomized every year (Gomez and Gomez 1984). Elementary plot size was $6 \times 5=30 \mathrm{~m}^{2}$, each plot consisting of 10 rows $50 \mathrm{~cm}$ apart. On 17 December 2003, 15 December 2004, 18 December 2005, and 23 December 2006, seeds were manually arranged in rows, to obtain (according to seed germinability) plant populations of 40, 24 and 50 plants $/ \mathrm{m}^{2}$ for coriander, fennel, and psyllium, respectively.

In the whole trial period, five weeding methods were tested, but the treatments under observation were not the same in all years. From 2003-2004 to 2005-2006, three weeding methods were tested: false seedbed, flaming, and mechanical weeding. Only one intervention was made for each treatment, and no combined procedure was followed; furthermore, interventions only concerned the inter-row spaces, whereas weeds growing in rows were hand-removed only once in each crop and season. Actually, the priority goal of this trial was not to define a strategy for weed control in our crops, which would surely require a combined approach, rather to initialize a study about the effect of each single treatment on crop performance and on emerged weed biomass. After each intervention, weeds were left undisturbed in the respective treated plot. At harvest, weeds were collected from each plot, and fresh weed biomass was determined.

False seedbed was applied by means of shallow soil work using a rotary harrow (working depth, 3-4 cm), aimed to promote weed emergence. After the first autumn rainfall, i.e., about 4 weeks after this operation, the emerged weed seedlings were buried by means of another mechanical intervention performed with the same equipment. In $2003-$ 2004 and 2005-2006, the weather conditions allowed the treatment to be performed as planned, and crops were sown about 1 month after the normal date, i.e., on 18 January 2004 and 20 January 2006, respectively. However, in 20042005 , prolonged low temperatures and heavy rainfall, combined with the consequent unfeasible soil conditions, delayed false seeding to March 15, 2005. In the years when false seedbed was tested, a special test plot was sown along with the false seedbed treatment to assess possible differences due to sowing date delay irrespective to weed density. Because of the unsatisfactory seed yields obtained in the treatment with delayed sowing, in 2006-2007, both plots were substituted with other two treatments. One was an additional flaming method made with a different liquefied petroleum gas fired direct flaming weed tool dealing with one 50-mm nozzle (Kapriol, Morganti spa, Lecco, Italy). The second treatment was use of biodegradable plastic mulch, $15 \mu \mathrm{m}$ thick, based on cornstarch with Mater-Bi ${ }^{\circledR}$,
BioTelo Agri, Novamont, NO, Italy. The film, $70 \mathrm{~cm}$ wide, was manually laid in crop inter-rows after crop emergence and before the emergence of weeds, to cover the whole inter-row space.

Flaming was performed using special equipment (Mod. Lady, Silvio Zecchini Inc., Gualdo Tadino, FE, Italy) consisting of a $8 \times 20 \mathrm{~cm}$ propane-butane heating ceramic plate. The treatment was applied once per year in spring (MarchApril), as soon as the crops (still experiencing their vegetative phase) reached a canopy cover of about $25 \%$ and the majority of emerged weeds had not overpassed the four to five true leaf stage.

Mechanical weeding was performed about in the same dates, using a small hand-pushed rotary tiller with four hardened steel tines (McCulloch MFT81), with a working width of about $45 \mathrm{~cm}$ and at a depth of 5-7 cm, working in the inter-row spaces.

Two control plots were arranged each year to compare results: a positive control (hand weeding), in which weeds were manually removed by applying one or two interventions before complete crop seeds ripening, and a negative control (weedy plot), in which no weed control was done.

The growth and development of the crops were monitored throughout the trial. Average plant height was measured every week from crop emergence to harvest (five measurements for each survey), and the starting dates of the major development stages (crop emergence, onset of flowering, ripening of seeds) were determined by visual assessment of the average plot conditions.

In all treatments, the emergence of crop seedlings was recorded about 1 month after sowing. However, this occurred 7 (coriander and psyllium) to about 40 (fennel) days earlier in plots with delayed sowing, reasonably because of warmer soil temperatures. In all three crops, the vegetative phase ended as mean air temperatures started to rise. Hence, the onset of flowering was observed from mid-May until end of June, with the exact time varying by year and species. Each year, the majority of crop seeds reached the fully ripened stage in the last 10 days of June (coriander) and in mid-July (fennel and psyllium). At that stage, crops were manually harvested. In order to remove any border effect, a sample area $20 \mathrm{~m}^{2}$ wide was obtained by excluding the two external rows for each plot and all the plants within $0.5 \mathrm{~m}$ at the end of each row. All plants inside the sample area were cut at ground level; the biomass of all collected plants was measured and expressed in kilograms per hectare for further evaluations. After a short open-air drying, all collected plants were threshed to separate seeds from straw. The height (centimeters) of plants, the number of reproductive structures (umbels in coriander and fennel and flowers in psyllium), and the average number of seeds in each umbel or flower were measured from a representative sample of 20 plants per species and plot. 


\subsection{Data analysis}

All collected data were statistically analyzed according to the chosen experimental design using the SAS 9.0 software package (SAS Institute Inc., Cary, NC, USA, 2002). Prior to statistical analysis, the homogeneity of variances was checked through the Levene's test. An initial preliminary examination of the overall effect exerted by the two sources of variability in the linear model ("year," $Y$, and "treatment," $T)$ and by their interaction $(Y \times T)$ was carried out on all pooled data (data not shown). Since most analyzed variables had shown a significant $(P \leq 0.05)$ effect of $Y \times T$ interaction, which did not allow to discuss about pooled mean factors, the ANOVA was repeated separately for each trial year. When the $F$ test indicated statistical significance at the $P \leq 0.05$ level, Tukey's honestly significant difference test was used to separate the means.

Data obtained from the false seeding and its control were excluded from statistical analysis because of the very low productivity of those treatments, whose introduction in the post hoc evaluation scheme, while enhancing the "noise" of statistical analysis, did not add any relevant information.

\section{Results and discussion}

\subsection{Plant development and growth stages}

In plots sown under normal conditions, the total cycle duration was 180-194 days in coriander, 206-219 in fennel and 204-216 in psyllium, with no apparent variation due to the weed management method. However, the use of the false seedbed technique forced sowing to take place after the ideal date. In some cases, sowing was delayed up to 3 months because of unfavorable weather and soil conditions. Hence, in plots with delayed sowing, the total cycle had a shorter duration (97-178 dd in coriander, 103-133 in fennel and 114-179 in psyllium). Being the onset of flowering mostly controlled by a rise in air temperature, the delay in sowing had the greatest effect on the duration of vegetative stages (from crop emergence to flowering time), which were shortened by $16-66 \%$ (Figs. 2 and 3).

The occurrence of a tight direct influence of cycle duration on the general health conditions of coriander plants and, therefore, on yields was already assessed in a previous work (Carrubba et al. 2006). A similar response occurred in the 3 years when false sowing was tested, and in the delayed-

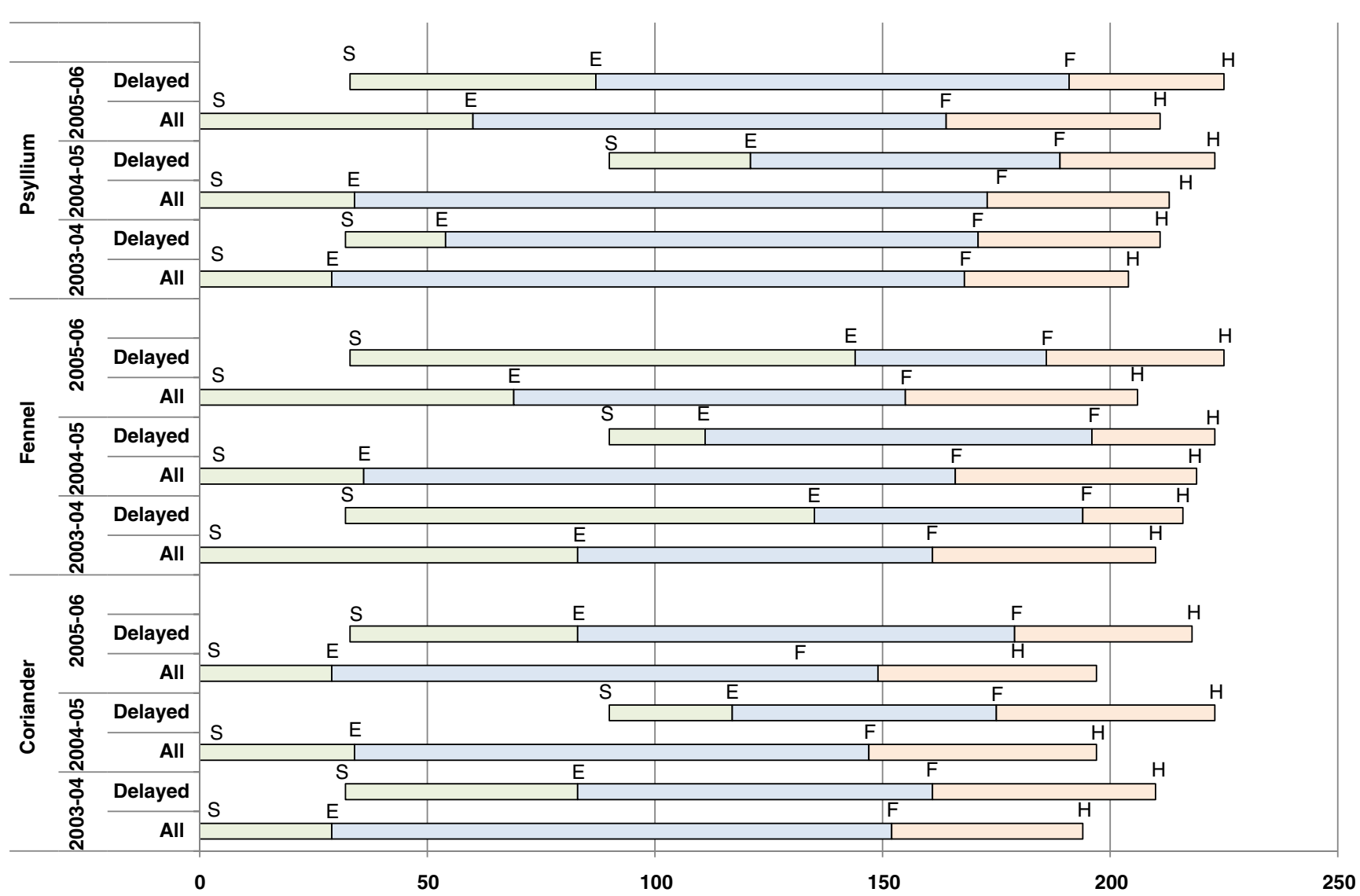

Fig. 2 Duration in days after sowing of the main development stages in coriander, fennel, and psyllium after diverse weeds control methods. Delayed: plots submitted to false sowing and their control; all, average value of all the other treatments; $S$ sowing, $E$ emergence, $F$ flowering, $H$ seeds harvest 


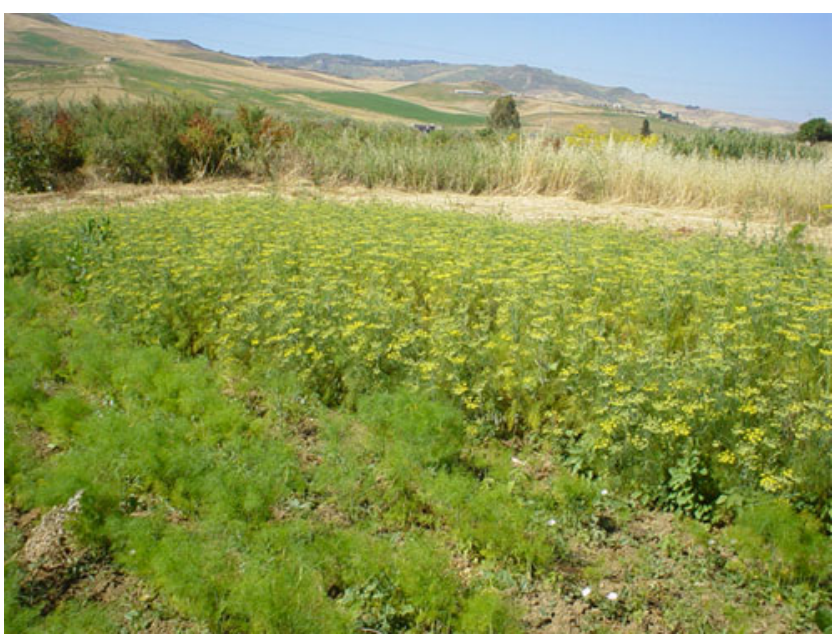

Fig. 3 The forced delay of sowing due to the stale seedbed technique generated a strong disadvantage of crops, which entered the dry season when seeds were not adequately ripe. On the left, delayed-sown fennel; on the right, fennel sown at proper time

sown plots, seed yields were always much lower than those measured in the weedy (untreated) controls. In 2004-2005 and 2005-2006, i.e., the less productive years, seeds yield did not even overpass $80 \mathrm{~kg} \mathrm{ha}^{-1}$, accounting for 11 and $14 \%$, respectively, of the yields obtained in each untreated (but sown at proper time) control. Although less definite, the same trend was also registered in fennel and psyllium, and in delayed-sown plots, seed yields showed a dramatic decrease (40-60\% in fennel, 40-90\% in psyllium) with respect to the other treatments.

Plant heights at harvest differed greatly within years and treatments (Table 1). The chosen statistical model was able to explain much of the total experimental variability in all species $(99.1,98.2$, and $97.8 \%$ for coriander, fennel, and psyllium, respectively). In the untreated (weedy) plots, plant heights averaged from about 92 to $134 \mathrm{~cm}$ (coriander), 59 to 106 (fennel), and 84 to 110 (psyllium), and the lowest values were measured for all three species in 2005-2006. Otherwise, in the positive (weed-free) control plots, plant heights reached lower values. The height of plants is often associated with their interspecific competitive ability (Freckleton and Watkinson 2001). This trend (higher plants with higher weed population) was actually evidenced in the two controls (weedy and weed-free), but in the controlled plots, a direct and definite association between these two parameters, although expected, was not recognized.

Plant biomass (Table 1) also showed great variability between years and between treatments within each year. The positive control reached in almost all years and crops higher biomass than in any treatment; conversely, in the untreated plots, plant dry biomass averaged much lower values, rather in all cases statistically different from the others. In all cases, crop biomass reached the maximum values in the plots with the lowest weed population and, conversely, the lowest value in the plots with the highest incidence of weeds.

\subsection{Seed yields and yield components}

Both seed yields and yield components (Table 1) experienced a high variability between years and treatments. In the weedfree plots, where the competition with weeds was lower and plants were able to express their optimum yield potential, seed yields ranged from 1,360 to $1,840 \mathrm{~kg} \mathrm{ha}^{-1}$ (coriander), 200 to $3,700 \mathrm{~kg} \mathrm{ha}^{-1}$ (fennel) and 340 to $1,540 \mathrm{~kg} \mathrm{ha}^{-1}$ (psyllium). Thus, yield data stress a higher stability over years in coriander with respect to the other two species, and this could confirm the greater suitability to field cultivation of coriander that retains fewer wild characters that are typical of many medicinal and aromatic plants.

The number of reproductive structures per plant (umbels in coriander and fennel, flowers in psyllium) and the number of seeds within them also evidenced significant differences in nearly all treatments and years (Table 1). In all three species and all year, the highest number of umbels and flowers per plant was recorded in the weed-free control, probably due to the lower interference from interspecific competition. In the weed-free plots, coriander carried between 16 and 30 umbels per plant, with 31-46 seeds each; fennel 3 and 11 umbels per plant, with 66-202 seeds each; and psyllium 44 and 86 flowers per plant, with $28-41$ seeds per flower.

A comparison between the effects of treatments on seed yields may be drawn from the graphs in Fig. 4, which show the relative yields for each treatment with respect to the weed-free control, considered as the ceiling yield under each specific experimental conditions.

As expected, all weeding treatments expressed seed yields between the two controls, demonstrating the importance of weed removal for yield performance and showing that they all were able to diminish weed competition. In all species and years, the absence of any weed control caused a dramatic reduction in yields, which, according to the different experimental conditions, ranged from 25 to about $95 \%$ of that obtained in the respective positive controls. It appears that, although none of the treatments showed a definite superiority in effectiveness, some difference in response may be evidenced between the species. In coriander, both mechanical and flame control had similar effects on yields, often comparable with those obtained in the weedfree controls. Otherwise, in fennel and psyllium, the effect of treatments was lower, and in most cases, the yield values were not statistically different from those obtained in the untreated (weedy) plots.

In all species, plants collected from the treated plots were often smaller and less productive than in untreated plots 
Table 1 Effect of different methods for nonchemical weed control on weeds biomass at harvest and on the major yield and growth traits in coriander, fennel, and psyllium, and results of ANOVA and Tukey's test for means within species and year

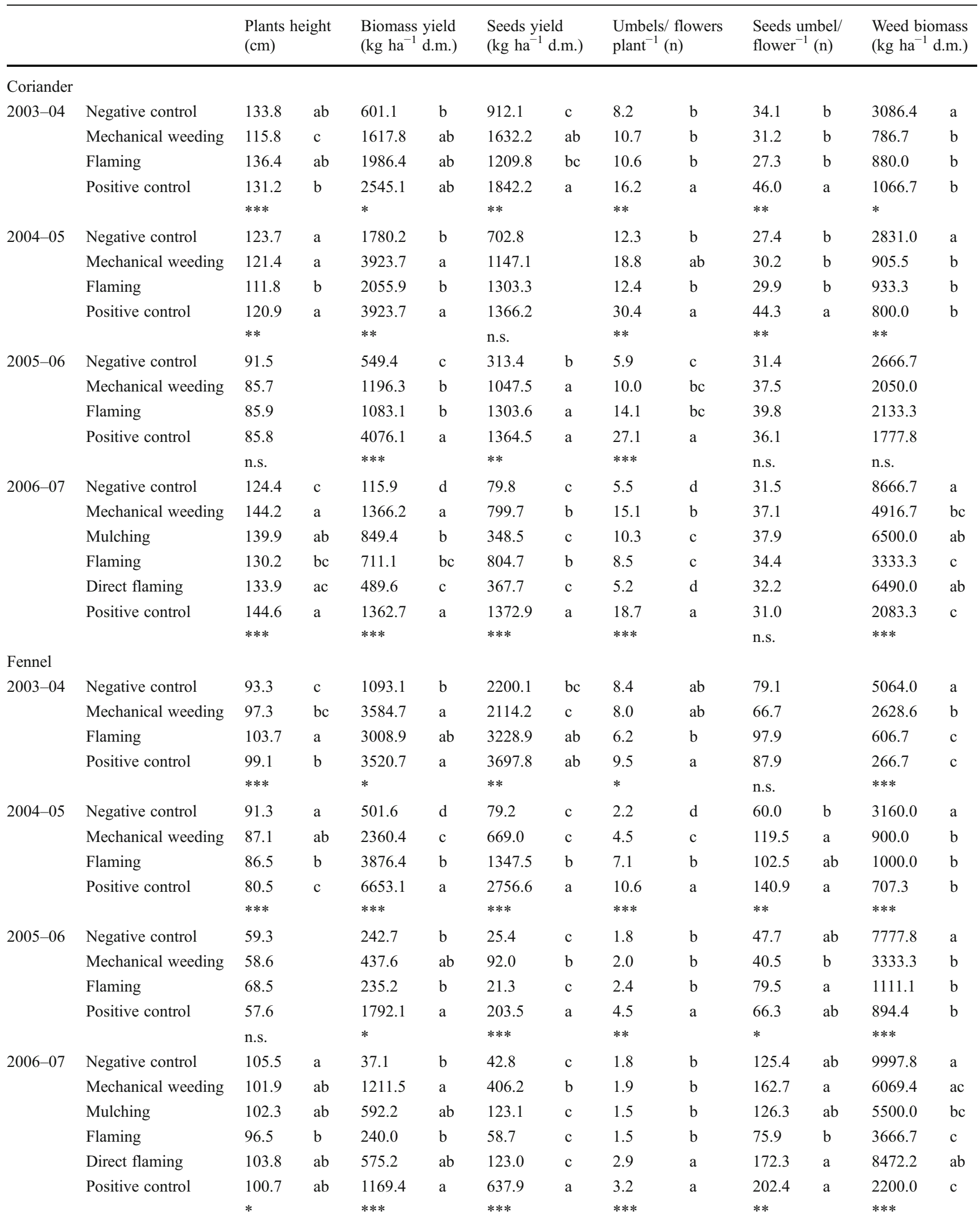


Table 1 (continued)

\begin{tabular}{|c|c|c|c|c|c|c|c|c|c|c|c|c|c|}
\hline \multirow{2}{*}{$\overline{\text { Psyllium }}$} & & \multicolumn{2}{|c|}{$\begin{array}{l}\text { Plants height } \\
(\mathrm{cm})\end{array}$} & \multicolumn{2}{|c|}{$\begin{array}{l}\text { Biomass yield } \\
\left(\mathrm{kgha}^{-1} \text { d.m. }\right)\end{array}$} & \multicolumn{2}{|c|}{$\begin{array}{l}\text { Seeds yield } \\
\left(\text { kgha }^{-1} \text { d.m. }\right)\end{array}$} & \multicolumn{2}{|c|}{$\begin{array}{l}\text { Umbels/ flowers } \\
\text { plant }^{-1}(\mathrm{n})\end{array}$} & \multicolumn{2}{|c|}{$\begin{array}{l}\text { Seeds umbel/ } \\
\text { flower }^{-1}(\mathrm{n})\end{array}$} & \multicolumn{2}{|c|}{$\begin{array}{l}\text { Weed biomass } \\
\left(\mathrm{kgha}^{-1} \text { d.m. }\right)\end{array}$} \\
\hline & & & & & & & & & & & & & \\
\hline \multirow[t]{5}{*}{ 2003-04 } & Negative control & 92.1 & $\mathrm{c}$ & 1287.2 & $\mathrm{~b}$ & 367.4 & $\mathrm{~b}$ & 29.0 & $\mathrm{ab}$ & 25.9 & $\mathrm{ab}$ & 7999.5 & $\mathrm{a}$ \\
\hline & Mechanical weeding & 100.0 & $\mathrm{~b}$ & 3086.2 & $\mathrm{a}$ & 454.0 & $\mathrm{~b}$ & 30.8 & $\mathrm{ab}$ & 27.4 & $a b$ & 513.3 & $\mathrm{~b}$ \\
\hline & Flaming & 118.9 & $\mathrm{a}$ & 1106.9 & $\mathrm{~b}$ & 537.9 & $\mathrm{~b}$ & 16.6 & $\mathrm{~b}$ & 24.3 & $\mathrm{~b}$ & 466.7 & $\mathrm{~b}$ \\
\hline & Positive control & 91.0 & $\mathrm{c}$ & 3254.6 & $\mathrm{a}$ & 1380.3 & $\mathrm{a}$ & 43.9 & $a b$ & 33.2 & $a b$ & 238.7 & $\mathrm{~b}$ \\
\hline & & $* * *$ & & $* *$ & & $* *$ & & $*$ & & $*$ & & $* * *$ & \\
\hline \multirow[t]{5}{*}{ 2004-05 } & Negative control & 95.3 & $\mathrm{~b}$ & 1576.3 & & 245.7 & & 16.1 & $\mathrm{~b}$ & 37.2 & $\mathrm{a}$ & 7560.0 & $\mathrm{a}$ \\
\hline & Mechanical weeding & 99.5 & $\mathrm{a}$ & 3480.8 & & 408.6 & & 60.8 & $\mathrm{a}$ & 19.5 & $\mathrm{~b}$ & 692.4 & $\mathrm{~b}$ \\
\hline & Flaming & 92.1 & $\mathrm{c}$ & 3826.8 & & 494.1 & & 62.0 & $\mathrm{a}$ & 23.9 & $\mathrm{~b}$ & 666.7 & $\mathrm{~b}$ \\
\hline & Positive control & 91.1 & $\mathrm{c}$ & 3885.2 & & 541.2 & & 86.4 & $\mathrm{a}$ & 38.2 & $\mathrm{~b}$ & 273.3 & $\mathrm{~b}$ \\
\hline & & $* * *$ & & n.s. & & n.s. & & $* * *$ & & $* * *$ & & $* * *$ & \\
\hline \multirow[t]{5}{*}{ 2005-06 } & Negative control & 84.2 & $\mathrm{a}$ & 1795.9 & $\mathrm{~b}$ & 36.5 & $\mathrm{~b}$ & 27.5 & $a b$ & 44.8 & $\mathrm{a}$ & 9491.1 & $\mathrm{a}$ \\
\hline & Mechanical weeding & 75.0 & $\mathrm{~b}$ & 3654.5 & $\mathrm{ab}$ & 152.4 & $\mathrm{~b}$ & 16.4 & $\mathrm{~b}$ & 28.8 & $\mathrm{~b}$ & 973.8 & $\mathrm{~b}$ \\
\hline & Flaming & 81.2 & $\mathrm{a}$ & 3219.9 & $a b$ & 117.9 & $\mathrm{~b}$ & 30.5 & $\mathrm{ab}$ & 41.0 & $a b$ & 586.5 & $\mathrm{~b}$ \\
\hline & Positive control & 81.4 & $\mathrm{a}$ & 4364.1 & $a b$ & 1542.7 & $\mathrm{a}$ & 44.0 & $\mathrm{a}$ & 41.0 & $a b$ & 345.0 & $\mathrm{~b}$ \\
\hline & & $* *$ & & $*$ & & $* * *$ & & $*$ & & $*$ & & $* * *$ & \\
\hline \multirow[t]{7}{*}{$2006-07$} & Negative control & 110.3 & $\mathrm{a}$ & 375.4 & & 19.4 & $\mathrm{c}$ & 8.6 & $\mathrm{~b}$ & 33.8 & & 8666.7 & $\mathrm{a}$ \\
\hline & Mechanical weeding & 92.4 & $\mathrm{bc}$ & 4626.7 & & 234.5 & $\mathrm{ab}$ & 23.5 & $\mathrm{~b}$ & 24.1 & & 6916.7 & $a b$ \\
\hline & Mulching & 88.4 & $\mathrm{c}$ & 2152.2 & & 52.1 & $\mathrm{bc}$ & 12.2 & $\mathrm{~b}$ & 19.9 & & 6166.7 & $\mathrm{ac}$ \\
\hline & Flaming & 87.8 & $\mathrm{c}$ & 2475.4 & & 76.5 & $\mathrm{bc}$ & 20.3 & $\mathrm{~b}$ & 29.6 & & 4999.9 & $\mathrm{bc}$ \\
\hline & Direct flaming & 104.7 & $\mathrm{ab}$ & 2521.3 & & 134.7 & $\mathrm{bc}$ & 12.5 & $\mathrm{~b}$ & 31.8 & & 8833.3 & $\mathrm{a}$ \\
\hline & Positive control & 90.1 & $\mathrm{bc}$ & 4487.4 & & 336.4 & $\mathrm{ab}$ & 74.7 & $\mathrm{a}$ & 28.4 & & 3001.0 & $\mathrm{c}$ \\
\hline & & $* *$ & & n.s. & & $* * *$ & & $* * *$ & & n.s. & & $* * *$ & \\
\hline
\end{tabular}

Each value is the mean of three replications. Within each species, year, and character, values followed by the same letters (including partials) are statistically not diverse at $P \leq 0.05$ (Tukey's HSD test)

n.s. not significant differences

${ }^{*} P \leq 0.01 ; * * P \leq 0.05 ; * * * P \leq 0.001$, significant differences within each species, year, and character, respectively

because of a simultaneous decrease in all yield parameters under consideration. It remains to be verified whether this effect arises because of injuries to the plant caused by the treatment or because of a greater effect of competition due to the prolonged presence of weeds.

\subsection{Weed biomass}

Weed biomass (Table 1) was measured at harvest on each plot to evaluate the effectiveness of each single treatment. Results of the pooled ANOVA (data not shown) illustrate the year effect to be highly significant for all species. In coriander, this effect explained nearly half (45.4\%) of the total experimental variability; otherwise, in fennel and psyllium, although the level of significance was the same for both year and treatment, the treatment effect explained a greater amount of variability (respectively for both sources of variability, $38.8 \%$ vs. $26.1 \%$ in fennel, and $54.2 \%$ vs. $13.8 \%$ in psyllium). Weed biomass, as expected, for all years and crops was higher in the untreated plots (from about 2.7 to $10 \mathrm{t} \mathrm{ha}^{-1}$ ). However, the presence of some lately sprouting weeds was recorded even in the handweeded (positive control) plots, but generally, that weed biomass was not much higher than $1 \mathrm{tha}^{-1}$, with the exception of the last trial year in all three crops (more than $2 \mathrm{t} \mathrm{ha}^{-1}$ of weeds). Weed biomass in all treatments comprised between the two extreme values showing some association with yield in that the highest weed biomass at harvest seems to be associated with the lowest values of crop biomass and seeds yield.

The relative effectiveness of weed control techniques may be deduced from the graphs in Fig. 5 .

As shown in Table 1, it is only in 2006-2007 that all treatments performed differently, although that year, they had a rather low ability in controlling weed population. In the majority of the other cases, weeding treatments revealed to be able to reduce the incidence of weeds between 50 and about $95 \%$. The hand-weeded plot, although not properly weed free, always showed the lowest values of weed biomass. However, in most cases, this value was not far different from those obtained with the other treatments. It is only in fennel that some differentiation showed up, and in 2 years 

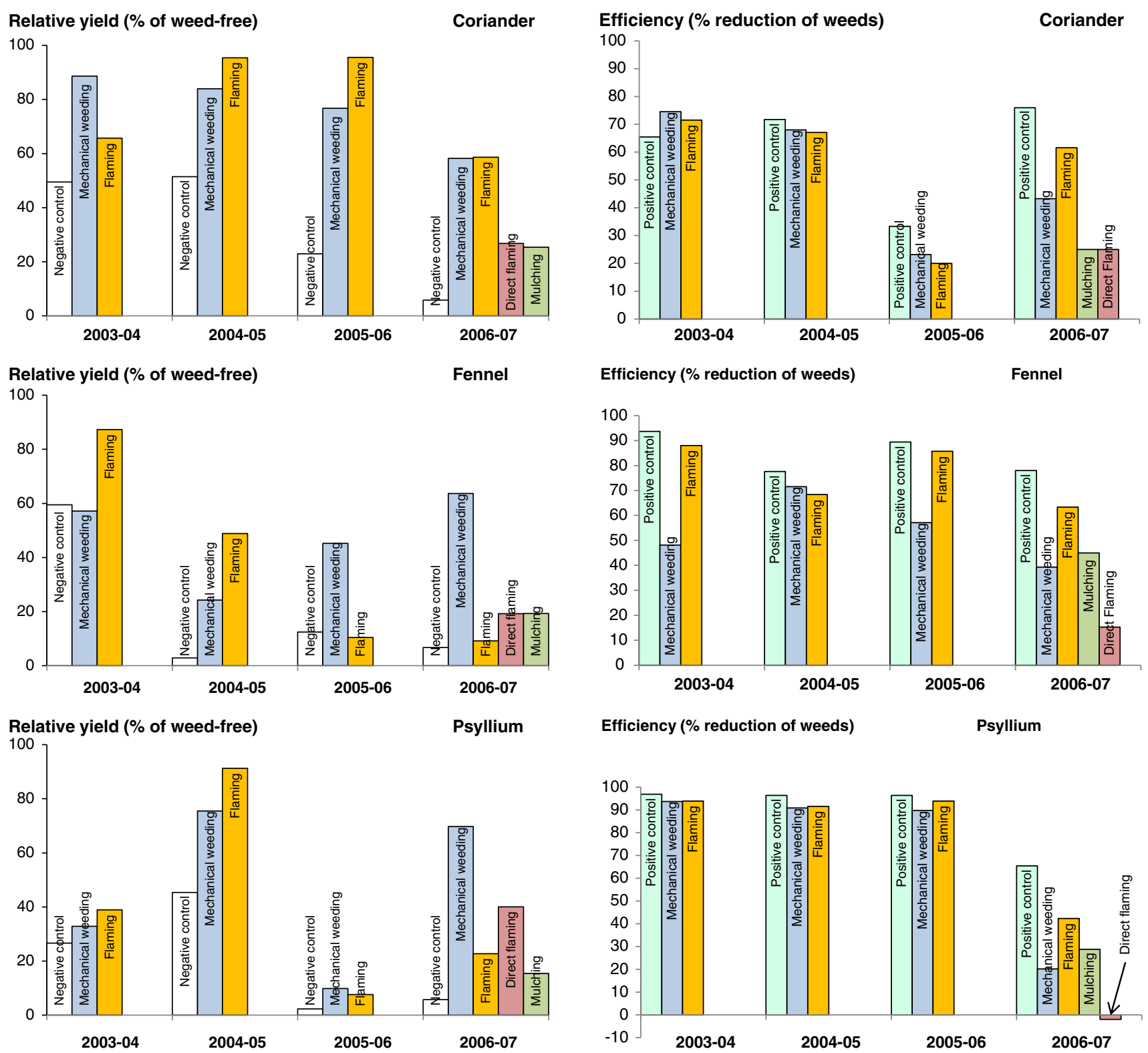

Fig. 4 Relative seed yields (\%) recorded in coriander, fennel, and psyllium with various weeding methods, with respect to a positive (weed-free) control, set equal to 100

over four, the mechanical weeding had a lower effectiveness in weeds control with respect to the other treatments. Van der Weide et al. (2008) already stated that mechanical weeding has a highly variable effect on weed biomass, which is heavily dependent on seasons and species. In most of our experimental cases, this technique was effective against weeds growing in inter-row spaces, although intra-row weeds were left undisturbed and reached a significant total biomass at harvest.

The application of an indirect heating on weeds, as done with the ceramic plate, was enough to exert a visible effect on weeds with a reduced injury on crops, allowing a reduction of weeds that ranged from 44 to $94 \%$ in respect to the

Psyllium

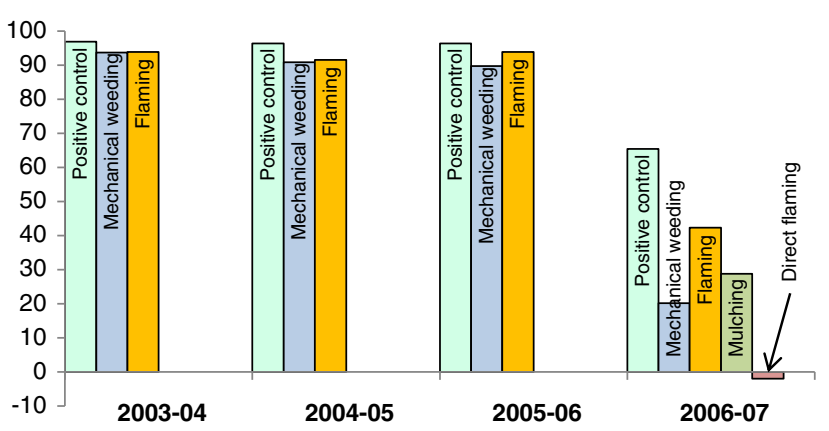

Fig. 5 Relative efficiency (\% reduction of weeds biomass) of some weeding methods in coriander, fennel, and psyllium, with respect to a negative (untreated) control, set equal to 0

untreated (negative) control. The use of direct flame, tested in 2006-2007, has shown a much lower effect than indirect flaming, and the levels of weeds biomass at harvest time were similar to those collected in the untreated plots. The low labor requirement is an important advantage of flaming, but intervention when weeds are still young and tender is crucial (Ascard 1995); hence, probably, an earlier intervention would have resulted in a better outcome.

Finally, mulching did not exert noticeable effects, and at harvest time in all three crops, a consistent weed biomass was weighed, originating from very aggressive spontaneous plants (Liliaceae and Chenopodiaceae) that were able to sprout breaking the plastic film. 


\section{Conclusion}

In all three crops, seed yield was strongly variable from year to year, which is normal in environments where lack of water and high temperatures can limit yields (Arnon 1992). Arguably, seed yield is a complex factor, resulting from diverse yield factors that determine seed production, individually or in combination, and in turn are affected in various ways by the chosen method of crop management.

There was an overall sensitivity of all three crops to the presence of weeds, which demonstrates the need of weed control techniques. In all three crops, the highest weed biomass at harvest actually seemed to be associated with the lowest values of crop biomass and seed yield. Apart from the extreme values obtained in the two controls (negative and positive), seed yield and crop biomass recorded in the weeded plots did not show any definite pattern, which means that treatments have interfered with the competitive mechanisms of crops. Fennel was already stated more sensitive to interspecific than to intraspecific competition (Carrubba et al. 2008), and according to the outcome of this trial, such a behavior could likely be extensible to the other two crops. Further experiments are necessary, however, in order to elucidate these aspects.

Another question is linked to the real effectiveness of the tested weeding treatments. As expected, no single treatment in the experimental plan could completely eradicate the weeds, which are endowed with great competitive ability and by the capability to develop a huge biomass rapidly. Thus, when planning a weed management strategy for such crops, more than one intervention should be advisable, and this validates the suggestion by Peruzzi (2005 and 2006) that an elastic approach to weed management should be adopted, using the available techniques, alone or in combination, in order to build proper tactics according to local conditions.

Our work stated clearly, however, that the diverse treatments exerted effects not only on weed population but also on crops themselves, and in a few cases, while giving satisfactory results in terms of containment of weeds population, they led to significant losses in grain yield.

Acknowledgments This study was funded by the Regional Government of Sicily-Assessorato Risorse Agricole e Forestali della regione Siciliana-Dipartimento Interventi Strutturali per l'Agricoltura. The authors are grateful to the anonymous referees and to the Editor-inChief of this journal, for their critical and constructive comments on the earlier version of this paper.

\section{References}

Anzalone A, Cirujeda A, Aibar J, Pardo G, Zaragoza C (2010) Effect of biodegradable mulch materials on weed control in processing tomatoes. Weed Technol 24:369-377. doi:10.1614/WT-09-020.1
Arnon I (1992) Agriculture in drylands: principles and practices. Elsevier, Amsterdam

Ascard J (1995) Effects of flame weeding on weed species at different developmental stages. Weed Res 35:397-411

Barberi P (2002) Weed management in organic agriculture: are we addressing the right issues? Weed Res 42:177-193. doi:10.1046/ j.1365-3180.2002.00277.x

Bond W, Grundy AC (2001) Non-chemical weed management in organic farming systems. Weed Res 41:383-405

Carrubba A, Calabrese I, Ascolillo V (2009) Non-chemical weeds management in two Mediterranean culinary herbs. Acta Hortic $826: 51-57$

Carrubba A, Catalano C (2009) Essential oil crops for sustainable agriculture - a review. In: Lichtfouse E (ed) Sustainable agriculture reviews: climate change, intercropping, pest control and beneficial microorganisms, sustainable agriculture reviews 2 . Springer, Berlin, 137-188. doi:10.1007/978-90-481-2716-0_8

Carrubba A, la Torre R (2005) Prove di pacciamatura organica su Origano (Origanum heracleoticum L.). Proc. XXXVI Convegno SIA. Foggia (Italy), 20-22 Sept 2005, pp 274-275 (in Italian)

Carrubba A, la Torre R, Matranga A (2002) Effect of the choice of different row arrangements on the bio-agronomical behaviour of Origanum heracleoticum. Acta Hortic 576:247-252

Carrubba A, la Torre R, Saiano F, Aiello P (2008) Sustainable production of fennel and dill by intercropping. Agron Sustain Dev 28:247-256. doi:10.1051/agro:2007040

Carrubba A, la Torre R, Saiano F, Alonzo G (2006) Effect of sowing time on coriander performance in a semiarid Mediterranean environment. Crop Sci 46:437-447. doi:10.2135/cropsci2005.0169

Carrubba A, Scalenghe R (2012) The scent of Mare Nostrum: medicinal and aromatic plants in Mediterranean soils. J Sci Food Agric 92:1150-1170. doi:10.1002/jsfa.5630

Chicouene D (2007) Mechanical destruction of weeds. A review. Agron Sustain Dev 27:19-27. doi:10.1051/agro:2006012

Cirujeda A, Aibar J, Anzalone Á, Martín-Closas L, Meco R, Moreno MM, Pardo A, Pelacho AM, Rojo F, Royo-Esnal A, Suso ML, Zaragoza C (2012) Biodegradable mulch instead of polyethylene for weed control of processing tomato production. Agron Sustain Dev 32:889-897. doi:10.1007/s13593-012-0084-y

De La Fuente EB, Gil A, Lenardis AE, Pereira ML, Suárez SA, Ghersa CM, Grass MY (2003) Response of winter crops differing in grain yield and essential oil production to some agronomic practices and environmental gradient in the Rolling Pampa, Argentina. Agric Ecosyst Environ 99:159-169. doi:10.1016/S0167-8809 (03)00131-2

Demarco MF, Sarruggieri H, Lopez MA (1999) Good agricultural practices for the organic production of medicinal plants. Acta Hortic 502:21-27

Diederichsen A (1996) Coriander (Coriandrum sativum L.). Promoting the conservation and use of underutilized and neglected crops. 3 . Institute of Plant Genetics and Crop Plant Research, Gatersleben/ International Plant Genetic Resources Institute, Rome

Duppong LM, Delate K, Liebman M, Horton R, Romero F, Kraus G, Petrich J, Chowdbury PK (2004) The effect of natural mulches on crop performance, weed suppression and biochemical constituents of Catnip and St. John's Wort. Crop Sci 44:861-869. doi:10.2135/ cropsci2004.8610

Europam - European Herb Growers Association (2010) Production of medicinal and aromatic plants in Europe. http://www.europam.net/ index.php?option $=$ com content $\&$ view $=$ article $\&$ id $=6 \&$ Itemid $=11$. Accessed 18 Oct 2012)

Fontana E, Hoeberechts J, Nicola S (2006) Effect of mulching in medicinal and aromatic plants in organic farm guest houses. Acta Hortic 723:405-410

Freckleton RP, Watkinson AR (2001) Predicting competition coefficients for plant mixture: reciprocity, transitivity and correlations 
with life-history traits. Ecol Lett 4:348-357. doi:10.1046/j.14610248.2001.00231.x

Galambosi B, Szebeni-Galambosi Z (1992) The use of black plastic mulch and ridges in the production of herbicide free herbs. Acta Hortic 306:353-356

Gil A, De La Fuente E, Lenardis A, Ghersa C, Van Baren HC, Di Leo Lira P, Suarez S, López Pereira M (1998) Yield and composition of coriander (Coriandrum sativum L.) essential oils related to soil environment and weed competition. Proc. Annual Conference "New Crops and New Uses: Biodiversity and Sustainability," Phoenix, 8-11 Nov 1998

Giorgi A, Mandrini S, Bona S (2006) Produzione di assenzio in Valle Camonica. Proc. III conv. naz. "Piante Mediterranee," Bari, 27 Sept-1 Oct 2006, p 120 (in Italian)

Gomez KA, Gomez AA (1984) Statistical procedures for agricultural research. Wiley, New York

Kasirajan S, Ngouajio M (2012) Polyethylene and biodegradable mulches for agricultural applications: a review. Agron Sustain Dev 32:501-529. doi:10.1007/s13593-011-0068-3

Kothari SK, Singh JP, Singh K (1989) Chemical weed control in Bulgarian coriander (Coriandrum sativum L.). Int J Pest Manag 35:2-5. doi:10.1080/09670878909371309

Marlett JA, Fischer MH (2003) The active fraction of psyllium seed husk. Proc Nutr Soc 62:207-209. doi:10.1079/PNS2002201

Martini A (1996) Prototipo per il pirodiserbo delle colture officinali. Proc. Int. Congr. "Coltivazione e miglioramento delle piante officinali," Trento, 2-3 Jun, 1994, pp 663-666 (in Italian)

Melander B, Rasmussen G (2001) Effects of cultural methods and physical weed control on intrarow weed numbers, manual weeding and marketable yield in direct-sown leek and bulb onion. Weed Res 41:491-508

Padulosi S, Leaman D, Quek P (2002) Challenges and opportunities in enhancing the conservation and use of medicinal and aromatic plants. In: Johnson CB, Franz C (eds) Breeding research on aromatic medicinal plants. Herbal Press, Haworth, pp 243267

Pank F (1992) The influence of chemical weed control on quality characters of medicinal plants. Acta Hortic 306:145-154

Peruzzi A (2005) La gestione fisica delle infestanti su carota biologica. Stamperia Editoriale Pisana, Agnano Pisano (in Italian)
Peruzzi A (2006) Il controllo fisico delle infestanti su spinacio in coltivazione biologica ed integrata nella bassa valle del Serchio. Stamperia Editoriale Pisana, Agnano Pisano (in Italian)

Rasmussen J, Henriksen CB, Griepentrog HW, Nielsen J (2011) Punch planting, flame weeding and delayed sowing to reduce intra-row weeds in row crops. Weed Res 51:489-498. doi:10.1111/j.13653180.2011.00858.x

Sangwan NS, Farooqi AHA, Shabih F, Sangwan RS (2001) Regulation of essential oil production in plants. Plant Growth Regul 34:3-21

Schippmann U, Leaman DJ, Cunningham AB (2002) Impact of cultivation and gathering of medicinal plants on biodiversity: global trends and issues. In: FAO, "Biodiversity and the ecosystem approach in agriculture, forestry and fisheries". Satellite event on the occasion of the Ninth Regular Session of the Commission on Genetic Resources for Food and Agriculture, 12-13 Oct 2002. Inter-departmental Working Group on Biological Diversity for Food and Agriculture, Rome. http://www.fao.org/DOCREP/005/ AA010E/AA010E00.HTM. Accessed 18 Oct 2012

Smith R, Lanini WT, Gaskell M, Mitchell J, Koike ST, Fouche C (2000) Weed management for organic crops, vol 7250. Division of Agriculture and Natural Resources Publications, University of California, Oakland

Van der Weide RY, Bleeker PO, Achten VTJM, Lotz LAP, Fogelberg F, Melander B (2008) Innovation in mechanical weed control in crop rows. Weed Res 48:215-224. doi:10.1111/j.1365-3180.2008.00629.x

WHO (1999) WHO monographs on selected medicinal plants, vol 1. WHO, Geneva, pp 202-212

WHO (2003) Guidelines on good agricultural and collection practices (GACP) for Medicinal and Aromatic Plants. WHO Publications, Geneva. 72 (available at http://apps.who.int/medicinedocs/pdf/ s4928e/s4928e.pdf last accessed on 18 October, 2012)

WHO (2007) WHO monographs on selected medicinal plants, vol 3. WHO, Geneva, pp 136-149

Zheljazkov V, Yankov B, Topalov V (1996) Effect of mechanical and chemical weed control on the growth, development and productivity of Mentha piperita and M. arvensis var. piperascens grown for planting material. J Essent Oil Res 2(8):171-176

Zheljazkov VD, Zhalnov I, Nedkov NK (2006) Herbicides for weed control in blessed thistle (Silybum marianum). Weed Technol 20:1030-1034 